\title{
A Study on Digital Literacy Skills of Faculty of Letters Students: Use of University Library
}

\author{
https://doi.org/10.3991/ijet.v16i01.16567
}

\author{
Burcu Umut Zan ${ }^{\circledR}{ }^{\bowtie}$, Huriye Çolaklar, Ahmet Altay, Nuri Taşkın \\ Bartın University, Bartın, Turkey \\ burcumutegmail.com
}

\begin{abstract}
The significance of the university libraries that directly support the universities' most fundamental duty, education activities, and researchdevelopment activities, is apparent when these duties are considered. Aiming to fulfill their responsibilities for modern university education, the university libraries try to satisfy the need of information that the academic society requires in today's world, in which the information and ways to obtain it is provided digitally, by attuning to the technological developments. This brings forth the necessity of those who wish to obtain information to possess a series of digital literacy skills. In university libraries where digital technology is used extensively, it is thought that users who do not have or have low digital literacy skills will not benefit from these libraries at the maximum level possible. Digital literacy skills are important, for university students, who are qualified human resources of countries, to have the digital literacy skills to meet the needs of the current age. It is therefore recognized that the determination of the digital literacy levels of the users, to whom services are provided, is important in diversifying the services and training provided to the users. This study is conducted to determine the current awareness and skills of students concerning digital literacy studying in the first grade of departments of Psychology, History, Turkish Language and Literature (TLL), and Contemporary Turkish Dialects and Literature (CTDL) at Bartın University. Using the quantitative research method, the data used in this study were obtained by using the survey technique. Within the framework of the responses of 226 participants to the survey questions, the study investigated whether there were any differences between students' digital literacy skills and awareness based on departments and technology usage habits. The study shows that students' skills and awareness about digital literacy vary according to the departments they study in and their technology usage habits. From this, it is suggested both to level the user educations prepared following the access to scientific information, and to provide the students with opportunities to improve their digital literacy skills, while keeping in mind that the students, to whom the university libraries serve, are of different digital literacy levels.
\end{abstract}

Keywords-University, a university library, digital literacy, digital literacy skills, university students. 


\section{Introduction}

The internet, the master network, increased the speed of transformation and production of information on the network. The integration of internet use into our lives has led to a change in the way that individual's access to information and their literacy understanding. Today, as the knowledge has become the most strategic factor affecting the development of countries, the most important capital has become the information capital [1]. The main source of information capital is qualified people. Universities are the academic institutions that train the much needed qualified human resources. In this process, what is expected from universities is to train the human resource that can reach the information, use the information, communicate and produce it, adapt to fast-changing technology, and learn by itself (learned how to learn) $[2,3]$. Since the fundamental duties of the students, beginning university to specialize in certain fields, are built around thinking, questioning, researching, and learning, a university library is a place where the students acquire the greatest support during their educational lives.

The development and change in information technologies have driven societies towards the information age, and this change has brought about differences in professions. While this period triggered the extinction of some professions, it radically changed some of them. The change in information technologies gradually began to show itself in library services in the 1980s [4]. Within this era, to make access to information seamless and to facilitate access to information, a lot of processes in library services have become electronic. When the user services offered in university libraries are taken into account, it has been observed that many steps require digital literacy. Those steps start with the registration of users and expand to include many matters, from scanning electronic and physical sources to locating a physical book within the library with references and borrowing the book; from extending the book's borrowing duration to paying penalty payments for delays; from ordering books to the library to using mobile library services; from accessing the desired sources by actively using the databases and using these sources effectively to accessing the library via remote access; and to changing the proxy settings of a computer to access the library via remote access, when necessary. In other words; the digital literacy skills of an individual, who is a newcomer into the academic society, has a key role for the development of that individual's habits to access the information which triggers academic success. While the university libraries have transformed into digital abreast with the current era, specifying the digital literacy skills is thought to be one of the best indicators for specifying the coherence of young library users with library services, because digital literacy skills are the tools that facilitate access to information offered by libraries. This study is conducted to determine the current awareness and skills of students concerning digital literacy studying in the first grade of different departments of the Faculty of Letters. The purpose of this study is to investigate the digital literacy skills of 1st graders in different departments of the faculty of letters, research their readiness for using technology-intensive library systems, and provide the libraries with suggestions in terms of the services they provide to students. 
The paper is structured as follows: The introduction part, followed by a theoretical outline within the scope of digital literacy, followed by similar studies in the relevant literature, and the research questions of this study, which are thought to support the literature. The later parts of the study include the method, findings, and results.

\subsection{Digital literacy: Theoretical framework}

The concept of "digital literacy", which constitutes the main subject of the work, was used by many authors in the 1990s to express the ability to read and understand hypertextual and multimedia texts. After a while, in 1997, Gilster, who popularized the concept of digital literacy, pointed out that this new literacy needs to be seen as a basic life skill [5]. Besides, digital literacy is regarded as a fundamental aspect of digital citizenship [6].

Martin [7] commented on many studies about digital literacy and formalized the definition of digital literacy, which is still prevalent, as follows.

"Digital Literacy is the awareness, attitude and ability of individuals to appropriately use digital tools and facilities to identify, access, manage, integrate, evaluate, analyze and synthesize digital resources, construct new knowledge, create media expressions, and communicate with others, in the context of specific life situations, to enable constructive social action; and to reflect upon this process."

It is possible to define digital literacy as the skills of finding information, deciding and analyzing whether the information is right/wrong, up-to-date/old, scientific/popular, etc., using that information to produce another information, and sharing information, by using different current digital technologies [8]. When the definitions regarding this term are inspected, it is observed that the digital literacy skills that emphasize the act of using the information in the digital environment point towards facilitating the education activities. Similarly, at a study about digital literacy done in 2011, Belshaw defined digital literacy as practices that support effective learning in the digital era [9]. In this respect, digital literacy skills, which are regarded as a part of education, are thought to be, without a doubt, important for effective library use as well in terms of finding and using the information in the digital environment.

\subsection{Literature assessment}

Since an individual needs digital literacy skills as well as critical thinking, questioning, and effective assessment abilities to access the complete, true, absolute, and up-to-date information that they require $[10,11]$, it has been observed that many studies based on digital literacy in the literature are in the education field. Despite national and international studies have been found on digital literacy in the field of education, it has been observed that not enough work has been performed at the national level in the field of library and Information sciences, which is considered as a part of education. However, there are different studies on digital literacy being conducted internationally with different perspectives. In this part of the study, the studies produced in and after the year 2015 were considered to provide more up-to-date publications and opinions while evaluating international literature. 
The shortest description of digital literacy is the one made by Eshet-Alkalai [12] as; "survival skill in the digital era". According to $\mathrm{Ng} \mathrm{[13],} \mathrm{the} \mathrm{indicator} \mathrm{of} \mathrm{an} \mathrm{indi-}$ vidual's being digital literate is her/his adaptation to the new or emerging technologies. When the relevant literature in the library and information science field is examined, it is observed that the works related to digital literacy among libraries were done in public $[14,15]$ and in university libraries $[16,17,18]$. Additionally, since frequent use of information technology tools in education and research studies and due to the responsibility of library employees to educate and teach library users; the digital literacy skills of librarians and users are thought to be important [19]. Therefore, when the studies are evaluated, it is observed that digital literacy skills were investigated for both library users and library employees.

In current investigations conducted on whether the digital literacy skills of library employees had an impact on the services provided in the library $[17,18,20]$. In the context of digital literacy skills, it was found that library employees had basic digital competencies such as electronic mail, social networking, the personal use of digital assistants, and internet browsing habits [17, 20]. It was emphasized that librarians acquired their digital literacy skills more through their colleagues, trial and error method, and formal education $[18,20]$. Also, investigations showed that there was no difference between digital literacy skills and gender, while there was a significant relationship between digital literacy skills and age, education, title, and work experience. It has been emphasized that the digital information literacy skills of the participants were positively affected by professional discipline, training, titles, and work experiences [18]. But it has been observed that the digital competences of librarians at foundation and state universities are changing [20]. Unlike these investigations, Martzoukou and Elliott [14] researched the digital literacy skills of librarians from a different perspective. In this study, researchers analyzed the library and information science programs' courses. As a result of the study, the gaps of 'Library and Information Science Specialization Programs' were identified in the areas based on the information technology skills. This result resembles that of previous studies. These studies result in the fact that the skills gained in MLIS (Master of Library and Information Science) are not sufficient to meet the IT skills expected by the employer [21, $22,23]$.

In general, it was stated in the literature that digital literacy competencies of librarians positively affect the services offered by the library and therefore these competencies should take into consideration in recruitment [17]. Besides, it was also emphasized that continuous support and education for librarians in the development of digital literacy skills is necessary to catch up with this digital era [14, 17, 18, 20, 24, 25]. It is possible to tie this associate with teacher education from the librarians' responsibility to educate the users. Even though the digital technologies are accepted to enrich the educational experience, the effective use of technology in education is thought to be related to the attitude of the teacher, and likewise, the librarian [26, 27]. From this point forth, the budget appropriated for the education of the teachers, and likewise, the librarians, is thought to be more important than the budget appropriated for the technology itself [27]. 
When the digital literacy skills of the librarians are compared, it is observed that fewer studies have been conducted about the library users' digital literacy skills. These studies focused more on sharing the digital library education experiences provided to the library users [16] or researching the academic successes of the students using the digital library [19].

If it is accepted that the tendency to use digital platforms for education will continue $[26,28,29]$, it must be thought upon how the libraries can support the users' education. Digital literacy and associated skills are becoming the basic and essential skill set of any students that wish to survive in a highly competitive world [30]. Especially; OPAC usage, virtual libraries, electronic research manual, digital library archive, open-access archive, databases, and online newspaper library, which are thought to be required for the library users to be able to use the digital tools in the library effectively and sufficiently. It is emphasized that the academic success of the students, who utilize digital literacy skills in their daily lives and can transfer these skills into using digital libraries, has been positively affected [19]. However, the students need to meet the digital opportunities in early ages for them to transfer their daily digital literacy skills into education [31]. When students can use media and technologies extensively to interact with their environment, they feel competent during the research, study, and creation of their digital work [32]. For this reason, Goulding, Shuker, and Dicker [15] researched the digital storytelling hours of preschool children in public libraries. The research found that while parents who did not participate in digital storytelling sessions were largely against the practice. On the other hand, the parents who participated at least one digital storytelling session had more positive views on meeting their children with digital media for the purpose of education at an early age [15]. It is important for education in early years to be performed via digital opportunities [26] considering that if the kindergarten or pre-school students can develop familiarity with educational computer activities in child libraries and be able to use various mobile devices relatively easier in later years.

Today's dynamic technological changes have left information-intensive associations, institutes, and universities facing challenges. Therefore, while the access of learners and researchers to digital information sources has become complex, it is observed that there are differences in information and digital literacy awareness that vary between both students and academic staff. Thus, the studies suggest that the librarians should take the responsibility to counsel the societies they serve about digital environments $[15,25]$. Especially university and research library employees, it must be remembered that all librarians play a big role in terms of obtaining scientific success by accessing modern academic digital opportunities, connections, and cooperations $[25,33]$. When the previous studies in the literature are observed while taking the responsibilities of the librarians into consideration, it has been detected that there are very few studies that focus on investigating the readiness of the students in terms of using the technology-intensive library systems by observing the students' digital literacy skills. Thus, our study is thought to be beneficial for the literature in terms of both researching the digital literacy skills of the students, each of whom is a potential library user, and providing suggestions regarding the library services and educations provided to the students, while considering the students' digital literacy skills. 


\subsection{Research questions}

The digital literacy skills and awareness of the first-grader university students, who will benefit from the university libraries that provide technology-intensive information service, are thought to be important for their adaptation into library systems. According to this acceptance, research questions of this study are listed below.

Do the digital literacy skills and awareness of first-grader university students, who will benefit from the university libraries that provide technology-intensive information service,

- Vary according to the students', departments?

- Vary according to the students' past experiences and ownership of using fundamental information technologies?

- Vary according to the students' income levels?

- Vary according to the students' gender?

At the end of the study, suggestions have been developed for library user relations according to the answers to these research questions.

\section{$2 \quad$ Method}

\subsection{Design of the research}

Quantitative research methods were used in this study to determine the existing skills and awareness of the students' relation to digital literacy studying in the first grade of departments of Psychology, History, Turkish Language and Literature (TLL), and Contemporary Turkish Dialects and Literature (CTDL) at the Faculty of Letters of Bartın University. The study was conducted during the 2019-2020 academic year. A three-part questionnaire was used to determine and evaluate the skills and awareness of the 226 students in digital literacy attending the first class in the Faculty of Letters.

\subsection{Data collection method}

The survey was used as a data collection tool. The questionnaire consists of two main sections. The first section contains categorical questions to determine the demographic information regarding the students and their ownership status of information technology tools.

The second section uses a digital literacy scale developed by $\mathrm{Ng}$ [13] and adapted to Turkish by Üstündağ et al [34]. A 5-point Likert scale was used to analyze the questions presented on the digital literacy scale. The 5-point Likert scale includes five options: "strongly agree-5", "agree-4", "neither agree, nor disagree-3", "disagree-2", "strongly disagree-1". The students are expected to obtain a maximum of 50 points from the digital literacy scale. The content validity of the scale is high by three expert academic members. Cronbach Alpha reliability coefficient was found as 0,946, corresponding to high reliability. 
Table 1 shows the questions directed to the students in terms of digital literacy scale and reliability.

Table 1. Details of digital literacy scale

\begin{tabular}{|l|l|c|}
\hline Dimension & \multicolumn{1}{|c|}{ Questions } & Reliability \\
\hline & $\begin{array}{l}\text { 1. I know how to solve my technical problems. } \\
\text { 2. I can learn new technologies easily. } \\
\text { 3. I keep up with important new technologies. } \\
\text { 4. I know about a lot of different technologies. } \\
\text { 5. I have the technical skills I need to use ICT for learning and to } \\
\text { create artifacts (e.g. presentations, digital stories, wikis, blogs) } \\
\text { that demonstrate my understanding of what I have learned. }\end{array}$ & \\
Digital & $\begin{array}{l}\text { 6. I have good ICT skills. } \\
\text { Siteracy }\end{array}$ & $\begin{array}{l}\text { 7. I am confident with my search and evaluate skills regarding } \\
\text { obtaining information from the Web. } \\
\text { 8. I am familiar with issues related to web-based activities e.g. } \\
\text { cyber safety, search issues, plagiarism. } \\
\text { 9. ICT enables me to collaborate better with my peers on project } \\
\text { work and other learning activities. } \\
\text { 10. I frequently obtain help with my university work from my } \\
\text { friends over the Internet e.g. through Skype, Facebook, Blogs. }\end{array}$ \\
\end{tabular}

\subsection{Target population and sampling}

While the target population of the study consists of a total of 280 students studying in the departments of Psychology (55), History (112), TLL (54), and CTDL (59) at Faculty of Letters of Bartın University, the sample of the study consists of a total of 226 students from these departments. The ratio of the sample to the target population is approximately $81 \%$. The ratio of the sample to represent the target population is sufficient for the reliability of the study [35].

\subsection{Analyzing the data}

Research data was encoded and recorded in SPSS 22 program. The interpretation of the findings was based on the p-value as a 0,05-significance level. Before the statistical analysis of whether the awareness and skills of the students related to digital literacy differed by gender, departments, and socio-economic status; the results of the survey were evaluated using the "Kolmogorov Smirnov Test" to determine whether the results present a normal distribution. Since, as a result of the evaluation, the value of significance (Assymp. Sig. $=p=0,00$ ) was less than 0,05, non-parametric test methods were used in the study. In this study, the Mann Whitney U Test and the Kruskal Wallis test were performed to test the significance of the difference between the means of the groups. Besides, descriptive analyses were used to present the numerical data of a single-valued variable. 


\subsection{Limitations}

It is accepted that the students who voluntarily participated in the study understood, and faithfully and correctly answered the questions directed to them. Also, all students are accepted to be active university library users. The study has been limited to students from Bartın University, Faculty of Letters. The classes that the students, who were admitted to the Faculty of Letters, took during their high school education have been accepted as equivalents.

\section{$3 \quad$ Findings}

A survey was conducted on 226 students who study in first grade at the departments of Psychology, History, TLL, and CTDL at the Faculty of Letters of Bartin University during the 2019-2020 academic year to determine the current skills and awareness of those students regarding digital literacy. Within the scope of the survey, data were collected under such titles as the demographic information of the students and their ownership of information technology tools, their habits of using information technology, and the digital literacy scale.

\subsection{Demographic findings}

In the survey applied to the participants, descriptive data about the gender, the departments, and the economic status of the students were obtained. Descriptive statistics regarding the demographic characteristics of the participants are presented in Table 2.

Table 2. Descriptive statistics regarding the demographic characteristics of the participants

\begin{tabular}{|l|c|c|}
\hline \multicolumn{1}{|c|}{ Gender } & Frequency & \% \\
\hline Female Department & 156 & 69 \\
\hline Male & 70 & 31 \\
\hline \multicolumn{1}{|c|}{ Pocket money (monthly) } & Frequency & $\%$ \\
\hline Department of Psychology & 53 & 23,5 \\
\hline Department of TLL & 51 & 22,6 \\
\hline Department of History & 72 & 31,9 \\
\hline Department of CTDL & 50 & 22,1 \\
\hline \multicolumn{2}{|c|}{} & Frequency \\
\hline Less than 250 TRY & 50 & 22,1 \\
\hline Between 250 and 500 TRY & 100 & 44,2 \\
\hline Between 501 and 750 TRY & 46 & 20,4 \\
\hline Between 751 and 1000 TRY & 22 & 9,7 \\
\hline Over 1000 TRY & 8 & 3,5 \\
\hline Total & 226 & 100 \\
\hline
\end{tabular}


When Table 1 is evaluated, it is observed that the participants consisted of $23,5 \%$ Psychology, 22,6\% TLL, 1,6\% History, and 22,1\% CTDL students. $69 \%$ of the students were female and $31 \%$ were male participants. To determine the economic level of the students, a question regarding the monthly pocket money of the students has been directed to them. According to the answers given to this question, it was determined that the pocket money of $44,2 \%$ of the students was between 250 and 500 TRY.

\subsection{Ownership of information technology tools}

Categorical questions have been directed to the participants for investigating the ownership of information technology tools, which are thought to affect the digital literacy skills of the students. Descriptive statistics on the use of information technology of the students within the scope of these questions are given in Table 3.

Table 3. Descriptive statistics on the use of information technology of the students

\begin{tabular}{|l|c|c|}
\hline \multicolumn{1}{|c|}{ Computer ownership } & Frequency & \% \\
\hline Yes & 161 & 71,2 \\
\hline No of owning a smart mobile phone & 65 & 28,8 \\
\hline \multicolumn{1}{|c|}{ Daily internet usage } & Frequency & 4 \\
\hline Before the age of 10 & 9 & 38,1 \\
\hline Between the ages of 10-13 & 86 & 50,9 \\
\hline Between the ages of 14-17 & 115 & 7,1 \\
\hline 18 and older & 16 & \% \\
\hline \multicolumn{1}{|c|}{ Frequency of switching mobile phones } & 39 & 17,2 \\
\hline 2 hours and less & 76 & 33,6 \\
\hline More than 2 hours to 4 hours & 111 & 49,1 \\
\hline 4 hours and more & Frequency & \% \\
\hline & 4 & 1,8 \\
\hline Once a year & 49 & 21,7 \\
\hline Once in 2 or 3 years & 95 & 42 \\
\hline When it's broken & 78 & 34,5 \\
\hline When it's unusable & 226 & 100 \\
\hline Total & & \\
\hline
\end{tabular}

When Table 2 is evaluated, it is observed that $71,2 \%$ of the students owned at least a personal tablet, desktop, or laptop computer. Still, the ratio of students who do not own a tablet, desktop, or laptop computer is $28,8 \%$. Another question that has been addressed to students in this section is about their age of owning their mobile phones. It has been observed that only $4 \%$ of students had a mobile phone before the age of 10 , while $38,1 \%$ owned a mobile phone between the ages of 10 and 13, and 50,9\% between the ages of 14 and 17. In other words, it is observed that the rate of owning a mobile phone in this age range has the greatest value. $7,1 \%$ of students stated that they owned a mobile phone after the age of 18. It is thought that starting a university education has a role in mobile phone ownership of these students. 
When the daily internet usage habits of the students were questioned, it was found that approximately half $(49,1 \%)$ of the students used the internet for more than 4 hours a day, and spent the majority of that time on social media. Students were also asked about the frequency of changing their mobile phones, which are the devices they spent the majority of their time using the internet. The majority of students $(76,5 \%)$ responded to this question that their cell phone was broken or nonusable.

\subsection{Digital literacy scale}

It is intended to measure the digital literacy skills of the students using the digital literacy scale developed by $\mathrm{Ng}$ [13] and adapted to Turkish by Üstündağ et al [34]. When the students could easily perform digital literacy practices, the maximum point from the scale was calculated as 50. In this case, scores of the departments from the digital literacy scale have been evaluated and are shown in Table 4.

Table 4. Mean values of digital literacy scale according to departments

\begin{tabular}{|l|c|c|c|}
\hline \multicolumn{1}{|c|}{ Departments } & N & Mean & Std. Deviation \\
\hline Department of Psychology & 53 & 37,0000 & 5,79788 \\
\hline Department of TLL & 51 & 37,8627 & 6,69633 \\
\hline Department of History & 72 & 34,0000 & 9,70117 \\
\hline Department of CTDL & 50 & 24,3200 & 9,78846 \\
\hline Total & 226 & 33,4336 & 9,71082 \\
\hline
\end{tabular}

The group, which indicated that they can easily perform digital literacy practices, consists of students of TLL department with 37,86 points. The students of TLL department are followed by the Psychology students and History students with 37,00 and 34,00 points, respectively. It has been observed that CTDL students obtained the lowest points with 24,32 points. The average of the digital literacy scare has been determined as 33,43 points. When the items in the digital literacy scale are evaluated, it has been observed that the items with the highest average are "I can learn new technologies easily." with 3,43 points, and "ICT enables me to collaborate better with my peers on project work and other learning activities." with 3,45 points in average out of 5. The item with the lowest average is "I have the technical skills I need to use ICT for learning and to create artifacts (e.g. presentations, digital stories, wikis, blogs) that demonstrate my understanding of what I have learned." with 3,25 points in average out of 5 .

The Kruskal Wallis test was conducted to test whether the digital literacy skills of the students differed by their departments. The results are presented in Table 5. 
Table 5. Kruskal Wallis Test, findings regarding the departments of the students

\begin{tabular}{|l|c|c|c|c|c|}
\hline \multicolumn{1}{|c|}{ Departments } & N & Average & Sd & $\mathbf{X}^{\mathbf{2}}$ & P \\
\hline Department of Psychology & 53 & 132,70 & & & \\
\cline { 1 - 3 } Department of TLL & 51 & 146,55 & \multirow{3}{*}{3} & \multirow{2}{*}{59,827} & \multirow{2}{*}{0,000} \\
\cline { 1 - 3 } Department of History & 72 & 117,46 & & & \\
\cline { 1 - 3 } Department of CTDL & 50 & 53,71 & & & \\
\hline
\end{tabular}

The results of the analysis show that the digital literacy skills of the students differed according to their department $(\mathrm{X} 2(\mathrm{sd}=3, \mathrm{n}=226)=59,827$, while $\mathrm{p}<0,05)$. It has been observed that the group of students with the highest average in terms of digital literacy skills is the TLL department, followed by the Psychology and History departments. While the score obtained from the scale average of the CTDL department was found to be quite low, the Mann Whitney U test was conducted to statistically test the difference between the departments. There was no statistically significant difference between the Psychology and TLL departments and between the Psychology and History departments regarding the scores students received on the digital literacy scale. It was noted that there was a statistically significant difference between the CTDL and History departments, CTDL and TLL departments, CTDL and Psychology departments, and TLL and History departments regarding the scores students received on the digital literacy scale.

The digital literacy skills of the students were assessed based on the age of smart mobile phone ownership of the students. The Kruskal Wallis test was conducted to test whether the age criteria for mobile phone ownership differed by the skills and awareness of the students. The results are presented in Table 6.

Table 6. Kruskal Wallis Test; findings regarding the age variable of the mobile phone ownership of the students

\begin{tabular}{|l|c|c|c|c|c|}
\hline \multicolumn{1}{|c|}{ Age of smart mobile phone ownership } & N & Average & Sd & $\mathbf{X}^{\mathbf{2}}$ & p \\
\cline { 1 - 3 } Before the age of 10 & 9 & 155,28 & & & \\
\cline { 1 - 3 } Between the ages of 10-13 & 86 & 112,12 & \multirow{3}{*}{3} & \multirow{2}{*}{22,911} & \multirow{2}{*}{0,000} \\
\cline { 1 - 3 } Between the ages of 14-17 & 115 & 114,99 & & & \\
\hline 18 and older & 16 & 43,69 & & & \\
\hline
\end{tabular}

The results of the analysis showed that the digital literacy skills of the students differed according to the age of mobile phone ownership $(X 2(s d=3, n=226)=22,911$, while $\left.\mathrm{p}<0,05^{\prime}\right)$. It has been observed that the group of students who received the highest average in terms of their skills and awareness of digital literacy is those who owned a mobile phone before the age of 10. While the lowest average in this group was the students with mobile phone ownership at age 18 and later, the Mann Whitney $\mathrm{U}$ test was performed to determine which groups had statistical differences. According to the results of the analysis, there were statistically significant differences between the students having mobile phones after the age of 18 and the students having mobile phones since the age of 16-18, 10-15, and before the age of 10 , while there was no significant difference between the other groups. 
The Mann-Whitney U test was conducted to test whether the digital literacy skills of the students differed by computer ownership. The results are presented in Table 7.

Table 7. Mann-Whitney U Test, computer ownership.

\begin{tabular}{|l|c|c|c|c|c|}
\hline & $\mathbf{N}$ & Average & Total & U & p \\
\cline { 1 - 4 } Owns a computer & 161 & 121,50 & 19561,00 & \multirow{2}{*}{3945,00} & \multirow{2}{*}{0,004} \\
\hline Does not own a computer & 65 & 93,69 & 6090,00 & \\
\hline
\end{tabular}

The results of the analysis showed that the digital literacy skills of the students significantly differed statistically according to their computer ownership ( $U=3945,00$, $\mathrm{p}=0,004, \mathrm{p}>0,05)$.

The study investigated whether the gender of the students, their departments, their economic status, and ownership of information technology tools statistically affect their digital literacy skills.

The Mann-Whitney U test was conducted to test whether the digital literacy skills of the students differed by gender. The results are presented in Table 8 .

Table 8. Mann-Whitney U Test, findings regarding gender

\begin{tabular}{|l|c|c|c|c|c|}
\hline & N & Average & Total & U & p \\
\cline { 1 - 4 } Female & 156 & 114,02 & 17787,50 & \multirow{2}{*}{5378,50} & \multirow{2}{*}{0,858} \\
\hline Male & 70 & 112,34 & 7863,50 & & \\
\hline
\end{tabular}

The results of the analysis show that the digital literacy skills of the students did not differ by gender: $U=5378,50, p>0,05$.

The Kruskal Wallis test was conducted to test whether the digital literacy skills and awareness of the students differed by the amount of their pocket money. The results are presented in Table 9.

Table 9. Kruskal Wallis Test; findings regarding the students' pocket money variable

\begin{tabular}{|c|c|c|c|c|c|}
\hline Income Status & $\mathbf{N}$ & Average & Sd & $\mathbf{X}^{2}$ & $\mathbf{p}$ \\
\hline Less than $250 \mathrm{TR}^{1}(34,7 \$)$ & 50 & 109,20 & \multirow{5}{*}{4} & \multirow{5}{*}{2,736} & \multirow{5}{*}{0,603} \\
\hline Between 251 and 500 TR $(35 \$-69,4 \$)$ & 100 & 112,39 & & & \\
\hline Between 501 and 750 TR $(70 \$-104 \$)$ & 46 & 120,75 & & & \\
\hline Between 751 and 1000 TR (105\$-139\$) & 22 & 103,30 & & & \\
\hline Over 1000 TRY (140\$>) & 8 & 140,69 & & & \\
\hline
\end{tabular}

The results of the analysis concluded that the digital literacy skills of the students did not differ according to the amount of pocket money they had $(\mathrm{X} 2(\mathrm{sd}=4$, $\mathrm{n}=226)=2,736, \mathrm{p}>0,05, \mathrm{p}=0,603)$.

${ }^{1} 1 \$$ adopted as $7,20 \mathrm{TR}$ 
Although it is observed that the students who receive the highest average in terms of their digital literacy skills and awareness are students whose pocket money amount is 1000 TRY and above, it is also seen that the scale averages are close to each other regardless of the amount of pocket money the students had.

The Kruskal Wallis test was conducted to test whether the digital literacy skills and awareness of the students differed by the daily internet usage of the students. The results are presented in Table 10.

Table 10. Kruskal Wallis Test; findings regarding the age variable of daily internet usage of the students

\begin{tabular}{|l|c|c|c|c|c|}
\hline \multicolumn{1}{|c|}{ Daily internet usage } & n & Average & Sd & $\mathbf{X}^{\mathbf{2}}$ & p \\
\hline 2 hours and less & 39 & 113,78 & & & \multirow{2}{*}{2} \\
\cline { 1 - 3 } More than 2 hours to 4 hours & 76 & 114,852 & \multirow{2}{*}{2} & 1,831 & 0,042 \\
\cline { 1 - 3 } More than 4 hours and more & 111 & 141,531 & & & \\
\hline
\end{tabular}

The results of the analysis concluded that the digital literacy skills of the students significantly differed statistically according to the daily internet usage of the students $(\mathrm{X} 2(\mathrm{sd}=2, \mathrm{n}=226)=1,831, \mathrm{p}>0,05, \mathrm{p}=0,042)$. The Mann Whitney U test was performed to determine which groups had statistical differences. According to the results of the analysis, there were statistically significant differences between the students whose daily internet usage more than 4 hours and students whose daily internet usage 4 hours and less.

\subsection{Categorical variables}

It has been found that the scale of digital literacy differed based on departments, according to the state of computer ownership, and to the mobile phone ownership age range. The findings are presented in cross tables in Table 11 to check whether there is a specific link between the relevant variables.

Table 11. Mobile phone ownership age and computer ownership by departments

\begin{tabular}{|c|c|c|c|c|c|c|}
\hline \multirow{2}{*}{\multicolumn{2}{|c|}{ Computer ownership }} & \multicolumn{4}{|c|}{ Age of owning a smart mobile phone } & \multirow{3}{*}{$\begin{array}{r}\text { Total } \\
43 \\
\end{array}$} \\
\hline & & \multirow{2}{*}{$\begin{array}{c}\begin{array}{c}\text { Before the age } \\
\text { of } 10\end{array} \\
4\end{array}$} & \multirow{2}{*}{$\begin{array}{c}\begin{array}{c}\text { Between the ages } \\
\text { of 10-13 }\end{array} \\
18\end{array}$} & \multirow{2}{*}{$\begin{array}{c}\text { Between the ages of } \\
14-17 \\
21\end{array}$} & \multirow{2}{*}{$\begin{array}{c}18 \text { and } \\
\text { older }\end{array}$} & \\
\hline \multirow{2}{*}{ Psychology } & Yes & & & & & \\
\hline & No & 0 & 0 & 10 & 0 & 10 \\
\hline \multirow{2}{*}{ TLL } & Yes & 0 & 18 & 22 & 0 & 40 \\
\hline & No & 0 & 1 & 10 & 0 & 11 \\
\hline \multirow{2}{*}{ History } & Yes & 2 & 23 & 22 & 0 & 47 \\
\hline & No & 2 & 6 & 15 & 2 & 25 \\
\hline \multirow{2}{*}{ CTDL } & Yes & 0 & 19 & 9 & 3 & 31 \\
\hline & No & 0 & 2 & 9 & 8 & 19 \\
\hline \multirow{2}{*}{ Total } & Yes & 6 & 78 & 74 & 3 & 161 \\
\hline & No & 2 & 9 & 44 & 10 & 65 \\
\hline
\end{tabular}


As presented in the previous sections of the study, the digital literacy skills of the Faculty of Letters students have an average value. However, the findings obtained from the study reveal that this situation of the students who are below the average value is related to their ownership of digital technologies. Table 11 reveals the general situation regarding the technology ownership of the Faculty of Letters students. When Table 11 is evaluated, it has been determined that $34,7 \%$ of the History department students, $38 \%$ of the CTDL department students, and $21,6 \%$ of the TLL department students did not own a tablet, desktop, or laptop computer. This rate has been determined to be $18,9 \%$ in the Psychology department. Overall, it has been observed that $7, .23 \%$ of students own at least a tablet, desktop or laptop computer. When the age of the students to own their mobile phone is evaluated, it has been determined that $22 \%$ of the CTDL students and 2,8\% of History students owned their mobile phones after the age of 18. It has been observed that the age of students to own their mobile phone is concentrated between 10 and 17 .

\section{Conclusions and Recommendations}

The change in information and communication technologies has affected universities and information centers in universities, just like every field. This has led university libraries to diversify their services based on digital technology that facilitates the access of users to information. The provision of technology-intensive services in university libraries has led to the questioning of the digital literacy skills of the employed staff and library users. It is known that university libraries provide constant education to their users for the efficient use of library information sources. For this reason, university library employees have a responsibility to educate their users. However, in university libraries where digital technology is used extensively, it is thought that users having or not having low digital literacy skills will not benefit from these libraries at the maximum level possible. Also, the determination of the digital literacy levels of the users, to whom services are provided, is important in diversifying the services and training provided to the users. Therefore, in the study, a research was carried out to determine the current digital literacy skills of 226 students attending the first class in departments of Psychology, History, Turkish Language and Literature, and Contemporary Turkish Language and Dialects at Bartın University. In this context, the digital literacy scale was used to evaluate the demographic information of the students and their ownership status of information technology tools, the habits of the students to use information technology, and their digital literacy skills.

As discussed earlier in the study, the ownership of information technologies is one of the basic conditions for digital literacy. Within this context, according to the answers, it has been observed that $71,2 \%$ of the students owned at least a personal tablet, desktop, or laptop computer. Similarly, to measure the impact of the age of owning their mobile phone on their digital literacy skills, their age of owning a mobile phone was examined. It has been observed that $90 \%$ of the students had their mobile phones between the ages of 10 and 17 . When the daily internet usage habits of the students were questioned, it has been found that approximately half of the students 
$(49,1 \%)$ used the internet for between 3 and 4 hours a day. Students were also asked about the frequency of changing their mobile phones, which are the devices they spent the majority of their time using the internet. The majority of students $(76,5 \%)$ responded to this question that their cell phone was broken or nonusable.

It has been found that the digital literacy skills of the students differed according to their departments. It has been determined that the lowest averages belonged to the students of CTDL, followed by the History department. It is also supported in the literature that scores from scales that determine levels of digital literacy vary according to the groups' technology ownership and time spent on the internet and computer [10]. Similarly, the findings in our study suggest that the digital literacy skills of the students differed according to the age of owning a mobile phone and the computer ownership.

When the computer ownership status and the age range of mobile phone ownership were examined according to the departments of the students, it has been determined that $29,17 \%$ of the students in History department and $38 \%$ in CTDL department did not own a computer, and also that the age of these students owning a mobile phone was later than that of the students of the other departments. It is noteworthy that there are students having mobile phones while they were young and not having computers in CTDL and History departments.

Results that are similar to those obtained in the study are supported by the literature as well. It causes an increase in the digital literacy levels if an individual met technology at an early age compared to those who met technology at older ages $[12,36]$.

Our study has found that the digital literacy skills of the students did not differ by gender. This result is similar to previous studies [11, 18, 37, 38]. It has also been concluded that the digital literacy skills of the students did not differ according to the amount of pocket money they had. The economic statuses of students are similar. Despite this, the reason why there is no difference between students with high and middle-low-income economic statuses is considered to be that regardless of the income status, they owned a smartphone that was connected to the network during a certain age range.

When the results obtained from the digital literacy scale are evaluated, it is observed that the students generally have an average of 3 and 3,45 for each item. This shows that they were caught in the middle between "neither agree, nor disagree" and "agree" options. An undergraduate student was confused in terms of the general performability since he/she is not aware of the extent to which he/she can perform the specified practice. This conclusion can be drawn from the average values of the results of the study. It emphasized that even the students of the departments with the highest points should improve their digital literacy skills. For a university student to fully benefit from the technology-intensive university library, the student's digital literacy level is expected to be higher. In this case, the university libraries must take responsibility. They must create environments and services that can especially improve the students' digital literacy skills. In terms of improving the digital literacy skills, environments must be created to develop the students' information strategy, to create environments in which discussions can be made on the network, and to gather information using the search engines, the students' improvement must be supported, 
and the student must realize his/her potential. As is known, improving digital literacy skills is related to technology ownership. This can also be observed from the results of the study. It is important to put every digital opportunity into service to equalize the opportunities of the students, especially those who do not own digital technology. University libraries should support the services they provide to their users with the materials that address the existing differences while taking into account the skills and differences of their users in digital literacy. For example, lending electronic book readers or tablets, or making efforts to support the created makerspace areas with materials ( $3 \mathrm{~d}$ printers) to address these differences.

It has been observed from the results obtained from the study that digital literacy skills varied depending on the department, even between students of the same department depending on their conditions. It has been seen that providing the user education sessions in the libraries collectively will not be very productive. Considering that the students with low digital literacy skills are hesitant of using the library services integrated into digital practices and that their opportunity for asking questions and performing practices will be limited during the in-group education sessions, it is needed to be supported by personal practices, rather than by groups, departments, or classes. At least university libraries should provide progressive training that is appropriate at all levels within the context of access to academic information while taking into account the skills and differences of their users in digital literacy.

Considering that the academic success of the Undergraduate student depends on the effort of the student, the extent to which the academician encourages the student, and the access to scientific information, it is seen that the academician, the students, and the library must be in coordination with one another. It must be remembered, in terms of the improvement of the student, that the library unit must make the academician aware of all of the opportunities, which the library provides, for accessing information, and share the opportunities for accessing information primarily with the academician. Especially in the current pandemic, transition into digitalization was rather quick. The students were required to continue remote education, regardless of their digital literacy skills, and this situation has shown how important digital literacy skills are. The issue of whether the students utilize the digital library opportunities during the remote education phase in a topic for another study.

University libraries are often described as the "intellectual heart" of universities. The impact of knowledge and digital literacy skills on achievements in the academic community is considered today as a great opportunity for librarians. This extends the potential of the on-campus service of the library staff, allowing the academy to serve as a digital facilitator and academic collaborator during this era of uneven distribution of digital skills.

Overall, the increasing digital talent is critical in terms of employability for students who have not only completed their undergraduate education, but are also about to start their career or can bring the skill sets they acquired during undergraduate education into the industry as well. Digital academia also means the development of new creative approaches for the collection, analysis, distribution, and reuse of research data. The world of e-research, which includes the changing digitalization steps along with the changing world order, reveals the necessity of managing the 
research data at all points of the research life cycle and working with the digital sources to demonstrate research impact. At this point, it is thought that well-trained library staff will play a strategic role in universities with their skills in information and digital literacy, especially in working with digital sources at all points of the research cycle [25].

University libraries are institutions that are expected to take an active role in the development of the digital literacy skills of the students. In this process, librarians are required to voluntarily undertake the digital media guidance task. The librarians must also be competent in digital literacy skills to undertake this task. In this case, the necessity of supporting the digital capabilities of library employees by continuous training arises $[17,18,24,25]$. This is because the skills learned by librarians during their education are not sufficient to meet the IT skills expected by their employers $[21,22,23]$.

In line with the results obtained from this study, some research suggestions have been listed below:

This study has been conducted with the students of Bartın University, Faculty of Letters. It should also be performed to determine the current digital literacy skills of students in math fields. Also, Bartın University is a developing university. The analysis of the current status of the students from well-established universities and comparison are suggested for the university libraries to diversify the services they provide and to re-build their user services.

\section{$5 \quad$ References}

[1] Adıgüzel, O. C., \& Berk, Ş. (2009). Mesleki ve teknik orta öğretimde yeni arayışlar: yeterliğe dayalı modüler sistemin değerlendirilmesi. Yüzüncü Yıl Üniversitesi, Eğitim Fakültesi Dergisi, 5(1): 220-236. https://doi.org/10.14527/9786052412138

[2] Akkoyunlu, B., \& Kurbanoğlu, S. (2003). Öğretmen adaylarının bilgi okuryazarlığı ve bilgisayar öz-yeterlik algıları üzerine bir çalışma. Hacettepe Üniversitesi Eğitim Fakültesi Dergisi, 24(24): 1-10. https://doi.org/10.17860/efd.08241

[3] Argon, T., Öztürk, Ç., \& Kılıçaslan, H. (2008). Sınıf öğretmenliği öğretmen adaylarının bilgi-okur-yazarlığı becerileri üzerine bir durum çalışması. Abant İzzet Baysal Üniversitesi Eğitim Fakültesi Dergisi, 8(2): 13-22. https://doi.org/10.17240/aibuefd.2017.17.30227-326 $\underline{605}$

[4] Yeşilorman, M., \& Koç, F. (2014). A critical view on the technological basis of an information society. Firat University Journal of Social Science, 24(1): 117-135.

[5] Gilster, P. (1997). Digital Literacy. New York: John Wiley.

[6] Ribble, M. (2015). Digital Citizenship in Schools: Nine Elements All Students Should Know (3rd ed.). Washington DC: International Society for Technology in Education.

[7] Martin, A. (2006). A European framework for digital literacy. Nordic Journal of Digital Literacy, 1(02): 151-161.

[8] Hamutoğlu, N., Güngören, Ö., Uyanık, G. K., \& Erdoğan, D. G. (2017). Dijital okuryazarlık ölçeği: Türkçe'ye uyarlama çalışması. Ege Eğitim Dergisi, 18(1): 408-429. https:// doi.org/10.12984/egeefd.329432 
[9] Belshaw, D. A. J. (2011). What is digital literacy? A Pragmatic investigation (DoktoraTezi, Durham Üniversitesi). Available at: http://neverendingthesis.com/doug-belshaw-eddthesis-final.pdf (Accessed April 11, 2020)

[10] Çetin, O. (2016). Pedagojik formasyon programı ile lisans eğitimi fen bilimleri öğretmen adaylarının dijital okuryazarlık düzeylerinin incelenmesi. Erzincan Üniversitesi Eğitim Fakültesi Dergisi, 18(2): 658-685. https://doi.org/10.17556/jef.01175

[11] Akkoyunlu, B., \& Soylu, Y. (2010). A study on teachers' digital empowerment. Turkish Librarianship, 24 (4): 748-768.

[12] Eshet-Alkalai, Y., \& Amichai-Hamburger, Y. (2004). Experiments in digital literacy. CyberPsychology \& Behavior, 7 (4): 421-429.

[13] Ng, W. (2012). Can we teach digital natives' digital literacy? Computers \& Education, 59(3): 1065-1078. https://doi.org/10.1016/j.compedu.2012.04.016

[14] Martzoukou, K., \& Elliott, J. (2016). The development of digital literacy and inclusion skills of public librarians. Communications in Information Literacy, 10(1): 99-115. https:// doi.org/10.15760/comminfolit.2016.10.1.17

[15] Goulding, A., Shuker, M. J., \& Dickie, J. (2018). Apps on laps: digital story times in public libraries in Aotearoa New Zealand. Library Hi Tech, 36(2): 252-269. https://doi. org/10.1108/lht-02-2017-0040

[16] Khan, S. S., \& Waheed, A. (2015). Digital literacy practices for library users at Government College University Libraries Lahore. Pakistan Library \& Information Science Journal, 46(4): 50-54.

[17] Emiri, O. (2015). Digital literacy skills among librarians in university libraries in the 21 st century in Edo and Delta States, Nigeria. International Journal of Scientific \& Technology Research, 4(8): 153-159. https://doi.org/10.4018/ijlis.2017010103

[18] Mansour, E. (2017). A survey of digital information literacy (DIL) among academic library and information professionals. Digital Library Perspectives, 33(2): 166-188. https://doi. org/10.1108/DLP-07-2016-0022

[19] Ukwoma, S. C., Iwundu, N. E., \& Iwundu, I. E. (2016). Digital literacy skills possessed by students of UNN, implications for effective learning, and performance. New Library World, 117(11/12): 702-720. https://doi.org/10.1108/NLW-08-2016-0061

[20] Khan, S. A., \& Bhatti, R. (2017). Digital competencies for developing and managing digital libraries: An investigation from university librarians in Pakistan. The Electronic Library, 35(3): 573-597. https://doi.org/10.1108/el-06-2016-0133

[21] Bosque, D.D. \& Lampert, C. (2009). A chance of storms: New librarians navigating technology tempests. Technical Services Quarterly, 26(4): 261-286. https://doi.org/10.1080 107317130802678878

[22] Gorman, M. (2004). Whither library education? New Library World, 105: 376-380. https:// doi.org/10.1108/03074800410557330

[23] Singh, V., \& Mehra, B. (2012). Strengths and weaknesses of the information technology curriculum in library and information science graduate programs. Journal of Librarianship and Information Science, 45(3): 219-231. https://doi.org/10.1177/0961000612448206

[24] Adams Becker, S., Cummins, M., Davis, A., \& Yuhnke, B. (2016). 2016 NMC technology outlook for Australian tertiary education: A Horizon project regional report. Austin, TX: The New Media Consortium. Available at: https://www.nmc.org/publication/2016-nmctechnology-outlookaustralian-tertiary-education/(Accessed April 12, 2020)

[25] Hallam, G., Thomas, A., \&Beach, B. (2018). Creating a connected future through information and digital literacy: Strategic directions at The University of Queensland Library. Journal of the Australian Library \&Information Association, 67(1): 42-54. https:// doi.org/10.1080/24750158.2018.1426365 
[26] Kalogiannakis, M., \& Papadakis, S. (2019). Evaluating pre-service kindergarten teachers' intention to adopt and use tablets into teaching practice for natural sciences. International Journal of Mobile Learning and Organisation, 13(1): 113-127. https://doi.org/10.1504/ijm 10.2019.10016617

[27] Papadakis, S. (2018). Evaluating pre-service teachers' acceptance of mobile devices with regards to their age and gender: a case study in Greece International Journal of Mobile Learning and Organisation, 12(4): 336-352. https://doi.org/10.1504/ijmlo.2018.10013372

[28] Papadakis, S., Kalogiannakis, M., Orfanakis, V., \& Zaranis, N. (2014). Novice Programming Environments. Scratch \&AppInventor: a first comparison. Proceedings of the 2014 Workshop on Interaction Design in Educational Environments, pp.1-7. ACM. https://doi.org/10.1145/2643604.2643613

[29] Papadakis, S., Kalogiannakis, M., Orfanakis, V., \& Zaranis, N. (2016) Using scratch and app inventor for teaching introductory programming in secondary education. A case study, International Journal of Technology Enhanced Learning, 8(3/4): 217-233. https://doi.org $\underline{\text { /10.1504/ijtel.2016.082317 }}$

[30] Phuapan, P., Viriyavejakul, C., \& Pimdee, P. (2016). An analysis of digital literacy skills among Thai University Seniors. International Journal of Emerging Technologies in Learning, 11(03): 24-31. https://doi.org/10.3991/ijet.v11i03.5301

[31] Papadakis, S., \& Kalogiannakis, M. (2019). Evaluating a course for teaching introductory programming with scratch to pre-service kindergarten teachers. International Journal of Technology Enhanced Learning, 11(3): 231-246. https://doi.org/10.1504/ijtel.2019.100204 $\underline{47}$

[32] Liu, Z., Tretyakova, N., Fedorov, V., \& Kharakhordina, M. (2020). Digital literacy and digital didactics as the basis for new learning models development. International Journal of Emerging Technologies in Learning, 15 (14): 4-18. https://doi.org/10.3991/ijet.v15i14.146 69

[33] Klassen, A. (2019). Deconstructing paper-lined cubicles: Digital literacy and information technology resources in the workplace. International Journal of Advanced Corporate Learning, 12(3): 5-13. https://doi.org/10.3991/ijac.v12i3.11170

[34] Üstündağ, M. T., Güneş, E., \& Bahçivan, E. (2017). Dijital okuryazarlık ölçeğinin Türkçeye uyarlanması ve fen bilgisi öğretmen adaylarının dijital okuryazarlık durumları. Journal of Education and Future, (12): 19-29. https://doi.org/10.16916/aded.593579

[35] Altunışık, R., Coşkun, R., Bayraktaroğlu, S., \& Yıldııı, E. (2012). Sosyal Bilimlerde AraştırmaYöntemleri (SPSS Uygulamalı). Sakarya: Sakarya Yayıncılık.

[36] Eshet-Alkalai, Y (2004). Digital literacy: A conceptual framework for survival skills in the digital era. Journal of Educational Multimedia and Hypermedia, 13 (1): 93-106.

[37] Kozan, M., \& Özek, M. B. (2019). Examination of the department of CEIT teacher candidates' digital literacy levels and cyberbullying sensitivities. Frrat University Journal of Social Sciences, 29(1): 107-120.

[38] İşman, A., \& Özdemir, N. (2018). A research on social media habits of university students: KTO Karatay University Facebook example. Akdeniz University Journal of Communication Faculty, (30): 89-103. https://doi.org/10.31123/akil.454292

\section{Authors}

Burcu Umut Zan works at the Bartın University in the Department of Information and Records Management with the title of associate professor. Also she is the head of 
Department of Information and Records Management at Bartın University. Bibliometry, information literacy and library ethics are her main working fields.

Huriye Çolaklar works at the Bartın University with the title of assistant professor in the Department of Information and Records Management. Information literacy and health literacy, digital libraries are the main working fields of her.

Ahmet Altay works at the Bartın University with the title of assistant professor in the Department of Information and Records Management. Information literacy, public libraries and digital libraries are the main working fields of his.

Nuri Taşkın works at the Bartın University with the title of assistant in the Department of Information and Records Management. He continues his PhD thesis about the subject of evaluating digital skills of libraries.

Article submitted 2020-06-25. Resubmitted 2020-09-04. Final acceptance 2020-09-04. Final version published as submitted by the authors. 